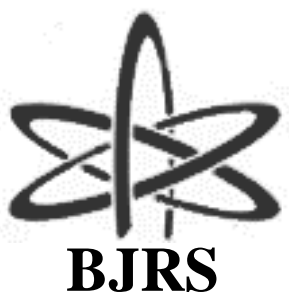
BRAZILIAN JOURNAL $\mathrm{OF}$ RADIATION SCIENCES 07-02B (2019) 01-17

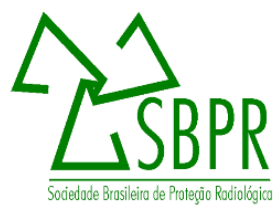

\title{
TRISO fuel thermal simulations in the LS-VHTR
}

\author{
$\operatorname{Ramos}^{a}$ M. C.; Scari ${ }^{a}$ M. E.; $\operatorname{Costa}^{a}$ A. L.; Pereira ${ }^{a}$ C.; Veloso ${ }^{a}$ M. A. F. \\ ${ }^{a}$ Universidade Federal de Minas Gerais - Departamento de Engenharia Nuclear \\ Av. Antônio Carlos, 6627, Campus Pampulha, 31270-901, Belo Horizonte, MG, Brasil \\ Instituto Nacional de Ciência e Tecnologia de Reatores Nucleares Inovadores/CNPq \\ antonella@nuclear.ufmg.br
}

\begin{abstract}
The liquid-salt-cooled very high-temperature reactor (LS-VHTR) is a reactor that presents very good characteristics in terms of energy production and safety aspects. It uses as fuel the TRISO particles immersed in a graphite matrix with a cylindrical shape called fuel compact, as moderator graphite and as coolant liquid salt Li2BeF4 called Flibe. This work evaluates the thermal hydraulic performance of the heat removal system and the reactor core by performing different simplifications to represent the reactor core and the fuel compact under steady-state conditions, starting the modeling from a single fuel element, until complete the studies with the entire core model developed in the RELAP5-3D code. Two models were considered for representation of the fuel compact, homogeneous and non-homogeneous models, as well as different geometries of the heat structures was considered. The aim to develop several models was to compare the thermal hydraulic characteristics resulting from the construction of a more economical and less discretized model with much more refined models that can lead to more complexes analyzes to representing TRISO effect particles in the fuel compact. The different results found, mainly, for the core temperature distributions are presented and discussed.
\end{abstract}

Keywords: Triso, LS-VHTR, Relap5-3D.

ISSN: 2319-0612

Accepted: 2019-02-22 


\section{INTRODUCTION}

The liquid-salt-cooled Very High Temperature Reactor (LS-VHTR) is one of the promising GENIV reactors due to its inherent safety features and its applications for hydrogen production [1]. It combines several new technology assets such as: the use of the TRiISOtopic (TRISO) fuel particles, high operating temperatures $\left(>750^{\circ} \mathrm{C}\right)$, Brayton power conversion cycle, passive safety systems and low pressure liquid-salt coolant. The LS-VHTR project goal is to provide an advanced design which offers the potential for higher power output, improved efficiency of electricity production, and higher operating temperatures leading to significant reduction in plant capital costs, as well as its use in high-temperature process heat applications [2].

The fuel of the LS-VHTR reactors is composed for coated particle called TRISO, which has a set of functional layers: fuel kernel, porous carbon layer, inner pyrolitic carbon (IPyC), Silicon carbide $(\mathrm{SiC})$, and outer pyrolitic carbon (OPyC). The main functions of the various layers are heat generation in the kernel, fission product retention in the porous layer, structural integrity in both pyrolitic carbons, and fission product barrier in the $\mathrm{SiC}$ [3].

These TRISO particles are incorporated into a graphite-matrix fuel compact, which, in turn, is loaded into a hexagonal fuel block which provides more control of the fuel and coolant volume fractions and geometry. This type of fuel can be subjected to temperatures up to $1600^{\circ} \mathrm{C}$ without damage. The TRISO fuel, a typical fuel compact and prismatic graphite block, which is the fuel assembly shape utilized in the LS-VHTR are shown in Figure 1 [4].

For the verification of its inherent safety of LS-VHTR, it is of great importance to analyze the thermal distribution of the core. However, the detail calculation for the entire core demands excessive computation resources due to effect the TRISO particles in the fuel compact. The thermo-physical fuel properties are crucial for a modeling and ensure that the modeled fuel is responding appropriately at the proper operating temperatures in the reactor. Therefore in this work, different simplifications have been realized to represent the fuel compact in the core reactor under steady-state conditions.

In the case of LS-VHTR fuel, there is little data available on the actual thermal conductivity of the TRISO particle, the only data available from the German experience with HTGR in the 1980s [5]. 
Moreover, to date, research on experimental measurements of the effective thermal conductivity of the compact fuel is restricted [6]. Therefore, the aim this work was to compare several models for representing the effect of the TRISO particles in the fuel compact, homogeneous and nonhomogeneous model were studied, the assumptions were made to model the fuel compact as accurately as possible.

\section{LS-VHTR REACTOR}

The reactor core configuration was initially introduced by the General Atomic (GA) Company [7] and has been extensively studied at Oak Ridge National Laboratory (ORNL) $[2,4,8]$. In the ORNL design of the FY-2005, a total of 265 columns of 10 fuel blocks stacked axially are assembled into a cylindrical geometry with nonfueled graphite reflector blocks filling in the region between the outer diameter of the core and the reactor vessel. A plan view of the core and reflector geometry is provided in Figure 1.

Figure 1: Design of the LS-VHTR core developed by ORNL of the FY-2005 [4], based in initial design of the General Atomic (GA) [7].

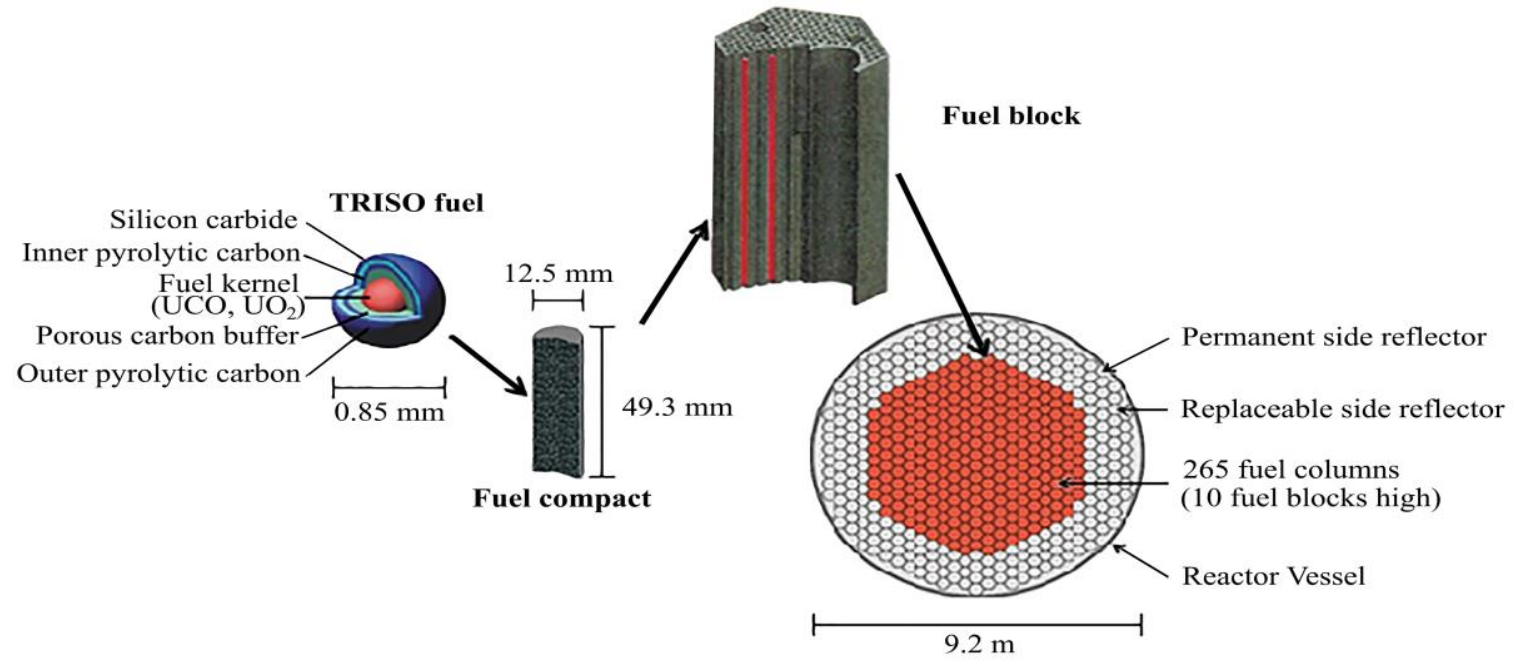

The cylindrical shape improved neutron economy, heat transfer, transport of liquid coolant and increase the total power output compared with the VHTR gas-cooled. LS-VHTR uses a closed 
primary cooled loop immersed in a tank containing a separate buffer salt. This design allows the use of a better salt in the primary coolant loop, that is, a salt that has better coolant properties but is not so good financially [4]. An elevation view of the FY-2005 reactor concept is shown in Figure 2.

For the primary loop, the FLiBe was selected, because of a high value of heat capacity, good radiation resistance, very low activation and neutronic absorption. The composition of the salt is $66 \% \mathrm{LiF}$ and $33 \% \mathrm{BeF}$. The melting point is $459^{\circ} \mathrm{C}$ and the boiling point is $1430^{\circ} \mathrm{C}$; the use of beryllium and enriched lithium makes this salt more expensive than other salts, but the overall performance is expected to be good. The advantage of the use of a molten salt is the atmospheric pressure core operation, which allows thinner and cheaper piping and vessel. Another advantage offered by FLiBe is the transparency which allows visual guidance of in-core operations during maintenance or refueling [9].

Figure 2: Elevation view of baseline LS-VHTR reactor developed by ORNL of the FY-2005.

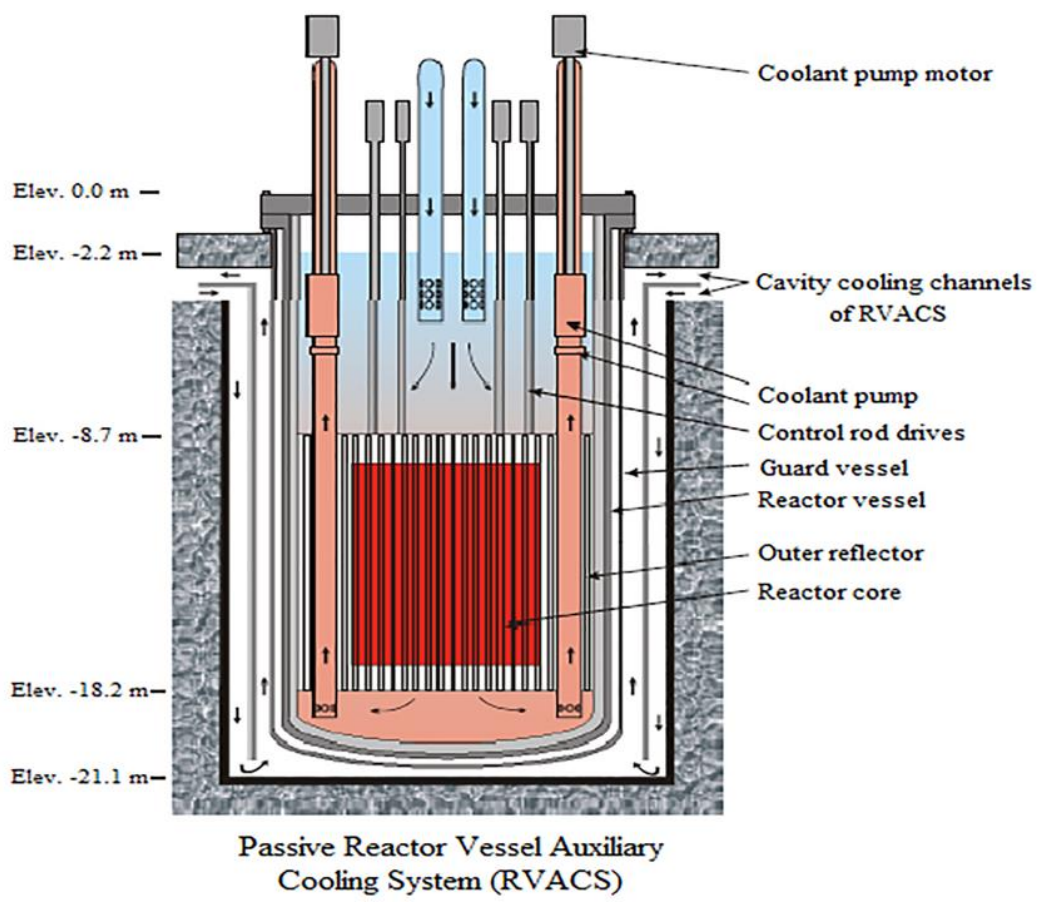

The baseline fuel block design considered is shown in Figure 3. This fuel block configuration option follows the FY-2005, baseline design developed by ORNL [4]. Each fuel block consists of a hexagonal element of 216 fuel channels, with diameter of $12.7 \mathrm{~mm}, 108$ coolant channels with 
diameter $9.53 \mathrm{~mm}$ and a fuel handling hole located at the center of fuel block that allows the assembly to be removed from the core. The flat-to-flat distance of the block is $360.0 \mathrm{~mm}$ and the distance between two channels is $19.0 \mathrm{~mm}$. The reflector blocks have the same dimensions as the fuel blocks, and are composed of graphite. The main parameters for the fuel assembly specified in the 2004 ORNL design of the LS-VHTR are shown in Table 1.

Figure 3: LS-VHTR hexagonal fuel assembly block [4].

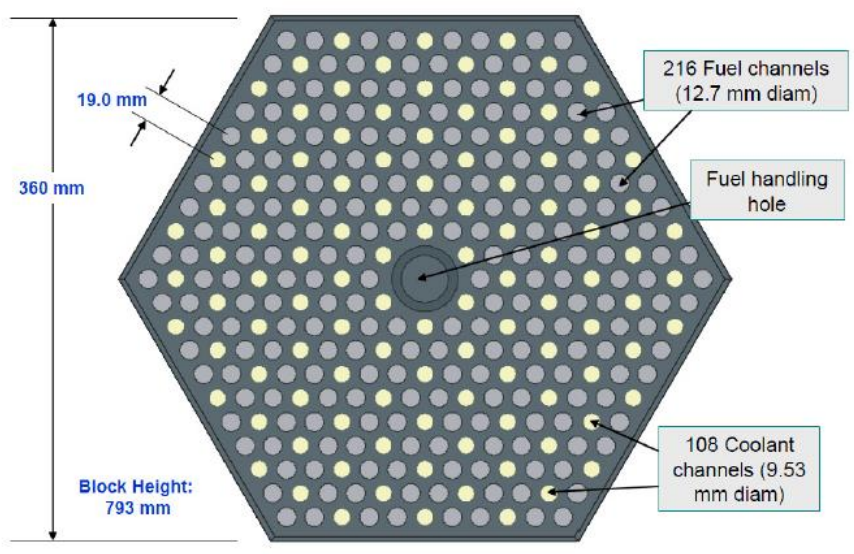

Table 1: Geometrical parameters of the LS-VHTR [4].

\begin{tabular}{lc|lc}
\hline \multicolumn{1}{c|}{ Parameter } & Value & \multicolumn{1}{c}{ Parameter } & Value \\
\hline Coated fuel particle: & & Fuel Block: & \\
-Fuel kernel composition & $\mathrm{UO}_{2}$ & - Graphite density & $1.74 \mathrm{~g} / \mathrm{cm}^{3}$ \\
-Fuel kernel density & $10.4 \mathrm{~g} / \mathrm{cm}^{3}$ & - Flat-to-flat distance & $36.0 \mathrm{~cm}$ \\
- Fuel kernel diameter & $350 \mu \mathrm{m}$ & - Heated length & $79.3 \mathrm{~cm}$ \\
- Particle diameter & $850 \mu \mathrm{m}$ & - Fuel channel diameter & $1.27 \mathrm{~cm}$ \\
Fuel compact: & & - Number of fuel channels & 216 \\
- Diameter & $1.25 \mathrm{~cm}$ & - Coolant channel diameter & $0.95 \mathrm{~cm}$ \\
- Length & $4.93 \mathrm{~cm}$ & -Number of coolant channels & 108 \\
- Number of compacts per fuel & 15 & - Pitch between channels & $1.90 \mathrm{~cm}$ \\
hole & & & \\
\hline
\end{tabular}




\section{METHODOLOGY}

The RELAP5 code was originally designed to simulate light water reactors (LWR). The new version of RELAP5-3D includes a variety of fluids and non-condensable gases, such as light and heavy water, helium, hydrogen, nitrogen, among others. The properties of several molten salts including FLiBe and FLiNaK have been subsequently incorporated to RELAP5-3D code [10].

The LS-VHTR core has been modelled using the RELAP5-3D code. In the developed model, 89 thermal hydraulic channels (THC) were considered to represent the 265 fuel columns of the core, that is, each thermal channel represents 3 LS-VHTR columns with the corresponding heat structure (HS). It was used 89 THC to reproduce with more details the core. The columns division to model the channels in RELAP5 is shown in Figure 4.

Figure 4: Columns division to representation in the core model.

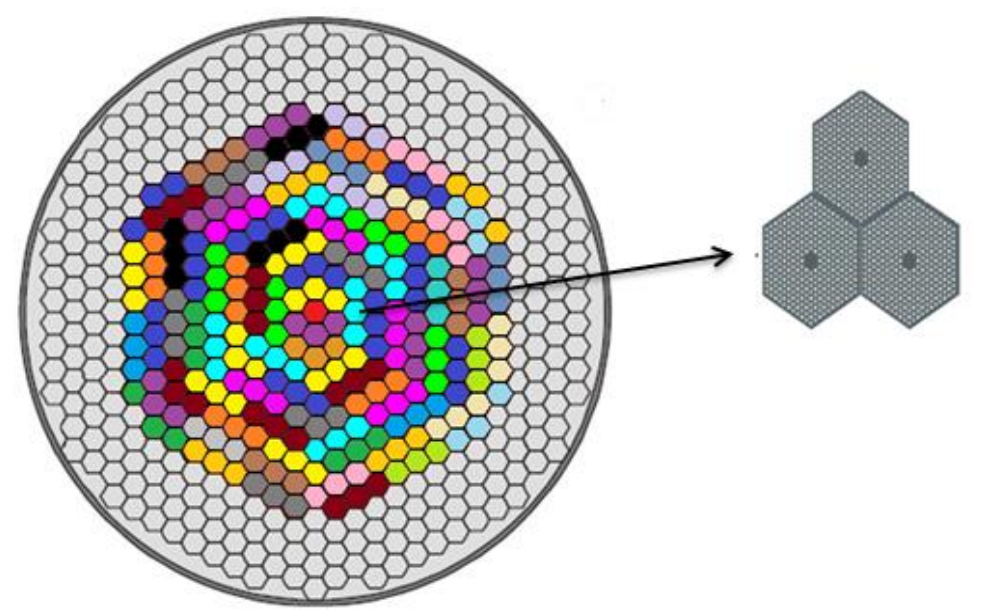

The complete core model is illustrated in Figure 5. The coolant channels were represented by the component type pipe from 301 to 389 corresponding to 3 LS-VHTR columns. The core was divided axially in 27 volumes, being that the active length of $7.93 \mathrm{~m}$ corresponds to 25 axial volumes and the inert parts correspond to the lower and upper reflectors of $0.8 \mathrm{~m}$. 
To simulate the thermodynamic conditions (flow, temperature, pressure) in all THC, the Time Dependent Volume (TMDPVOL) 101 and the single junction (SJ) 150 components represent the core inlet coolant. The TMDPVOL 500 and the SJ 450 components represent the core outlet coolant. Component of type BRANCH give an accurate physical description of the flow division or merging process of branched flows that occur in lower or upper plenum.

Figure 5: RELAP5-3D nodalization for the LS-VHTR core.

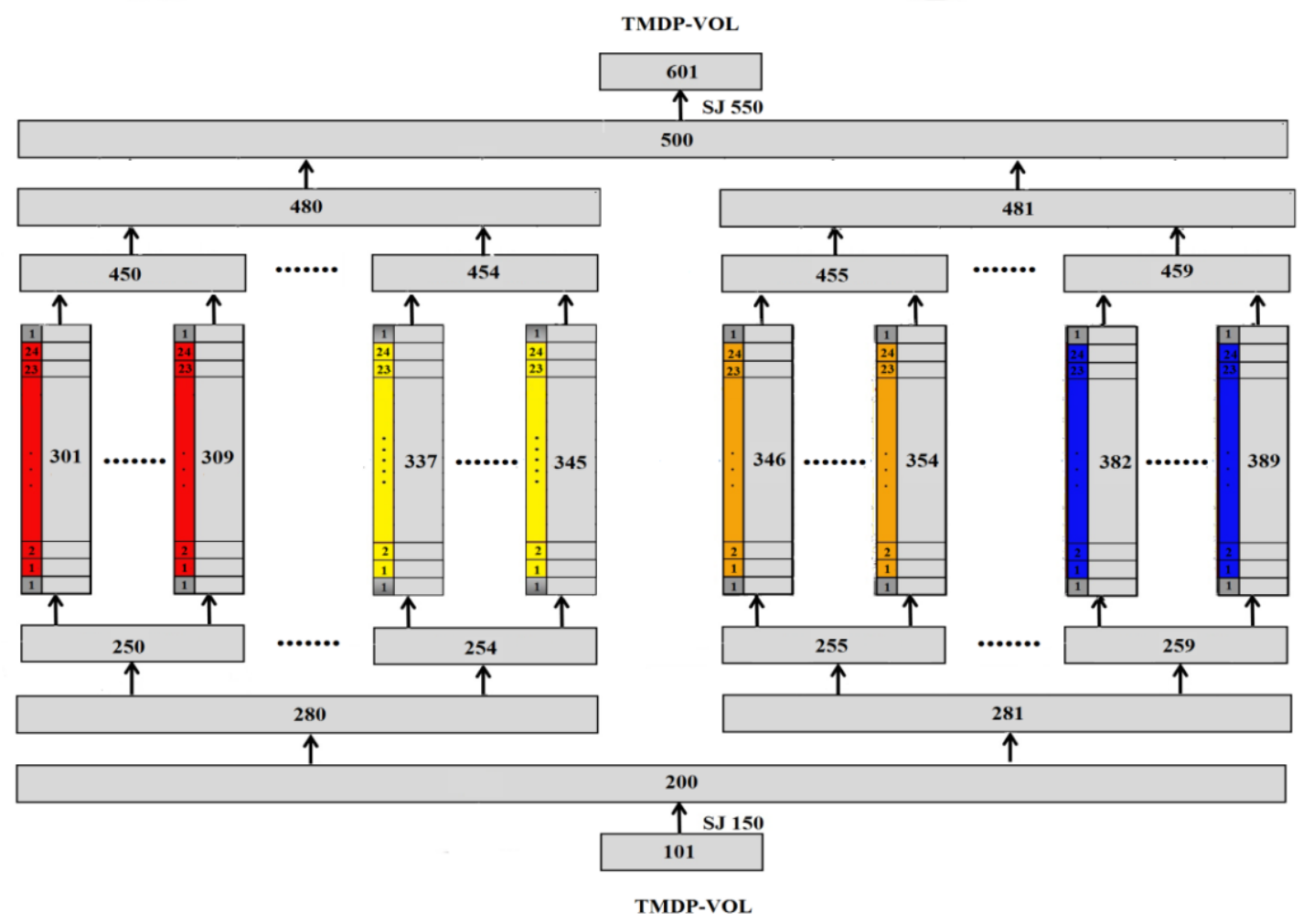

An initial thermal analysis of the LS-VHTR was performed in a previous work where the simulation of only one unit cell was considered in the RELAP5-3D code. Each unit cell, represented as a part of the hexagonal fuel block, was modeled to represent one coolant channel, filled with Flibe, and two fuel channels, with two gaps, immersed in graphite moderator matrix [11, 12].

In the present work, the unit cell was repeated throughout the active part of the core and this representation to model the core reactor as it is illustrated in Figure 4. Further two types of geometry were studied to represent this repeated cell. In Figure 6 are shown the representation of 
the cell used with (a) annular and (b) cylindrical geometry. It is important to note that these geometries were separately studied in different works, in which very-high-temperature reactor were modeled [13, 14]; however, there is no clear preference of which geometry is better to represent the unit cell.

In the model, a cylindrical and annular heat structure (HS) has been implemented for the core modeling. The RELAP5 code offers the capability to model the simple fuels configurations. The HSs simulates the power source and their outer boundary is attached to the corresponding coolant channel hydrodynamic component. They were divided axially in according with the same quantity of the thermal hydraulic channel volumes.

Figure 6: The annular and cylindrical geometries.
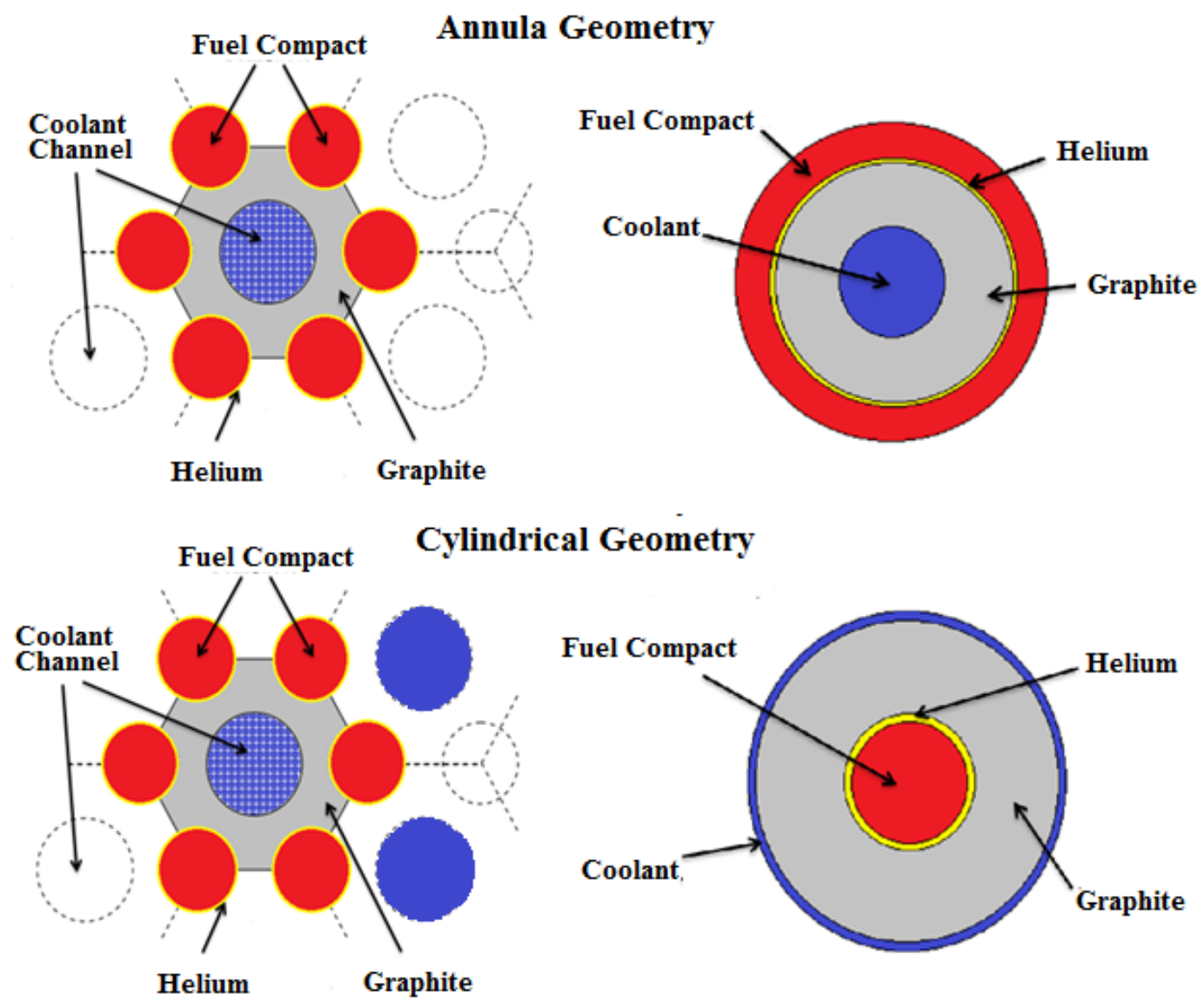
The fuel used in the LS-VHTR is a fuel compact, made of TRISO fuel particles assembled together in a graphite moderating matrix. Finding a model that would exactly reproduce the TRISO fuel performance was intricate. The assumptions were made to model the fuel as accurately as possible. Two models were studied for simulating the fuel compact, homogeneous and non-homogeneous model, as they are shown in Figure 7.

Figure 7: The homogeneous and non-homogeneous model.
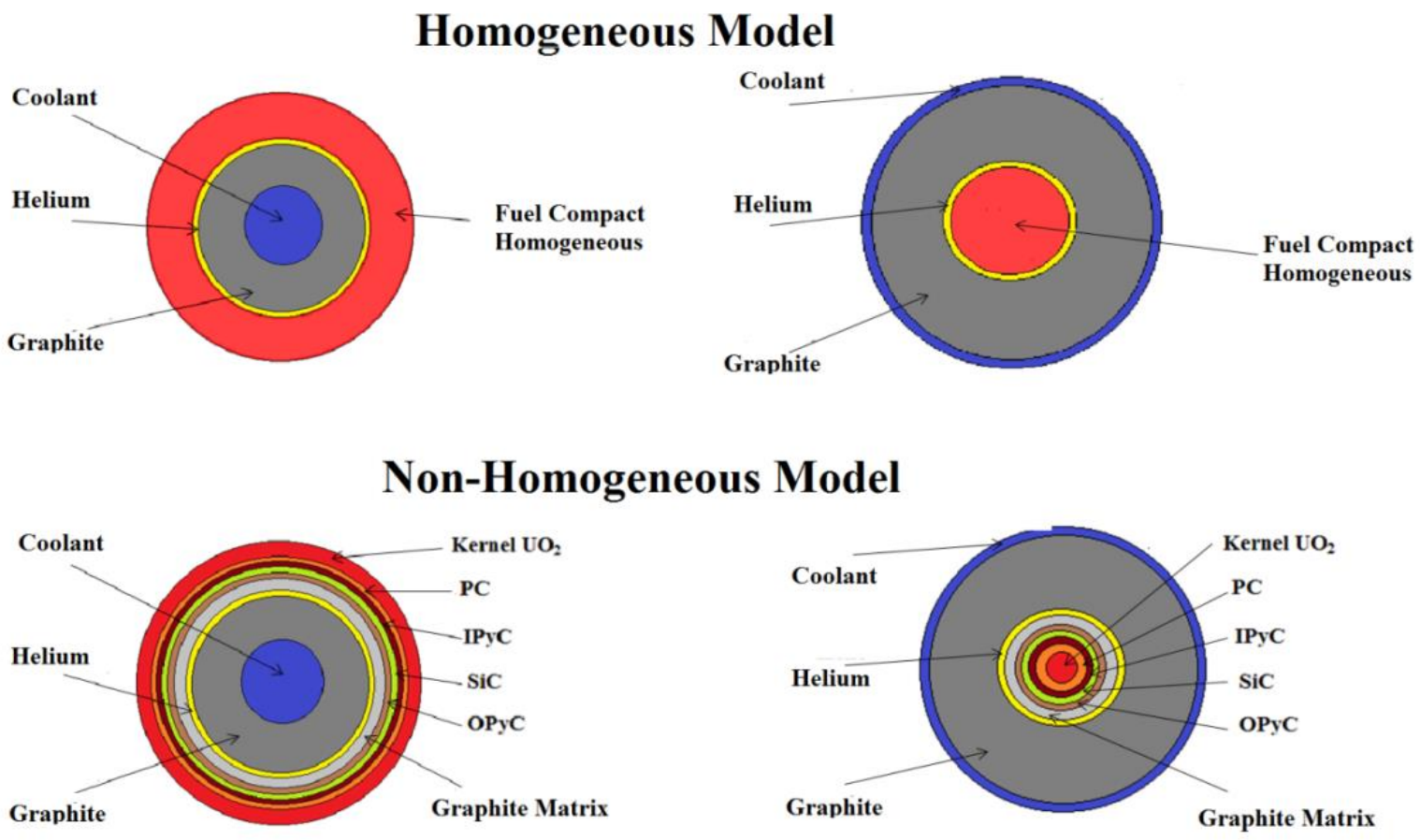

The homogeneous model consisted in determining the effective thermal properties of fuel compacts, using the thermal conductivity, heat capacity and volume fraction of each material of the TRISO fuel and graphite matrix. The effective thermal conductivity (ETC) properties of the compact fuel were determined by the same way as in the reference work [6] and [15] using the full version of the Maxwell's equation. The ETC gives homogenized thermal conductivity of heterogeneous material when each component is mixed randomly [16]. 
The non-homogeneous model consists in using separately the thermal properties of each material of the TRISO fuel and graphite matrix, the volume of each material was calculated using the proportion of TRISO particles in the fuel compact (packing fraction).

All heat structure has 16 radial meshes or 15 intervals, being 10 intervals to the fuel region in the case the homogeneous model, 1 interval for the helium gap and 4 intervals representing the graphite region. In the case of the non-homogeneous model, the 10 intervals of fuel region represent: the fuel kernel (4 intervals), the porous carbon (PC), inner pyrolitic carbon (IPyC), outer pyrolitic carbon (OPyC) and silicon carbide ( $\mathrm{SiC})$ each one represented by 1 interval. The graphite matrix is represented by 2 intervals. Each type of HSs is represented in Figure 8.

Figure 8: Heat structure represented in RELAP5-3D model.

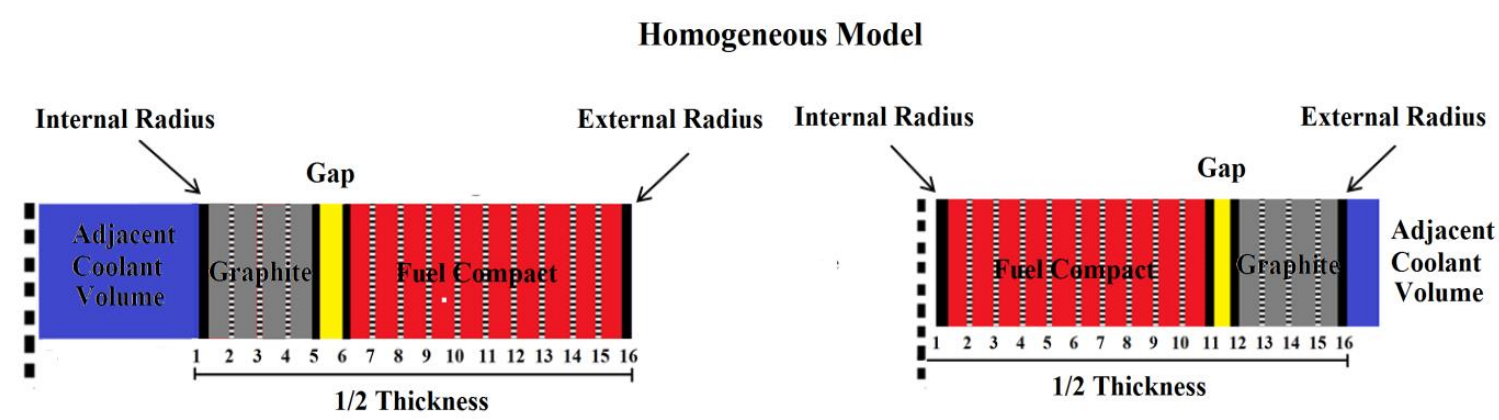

Non-Homogeneous Model

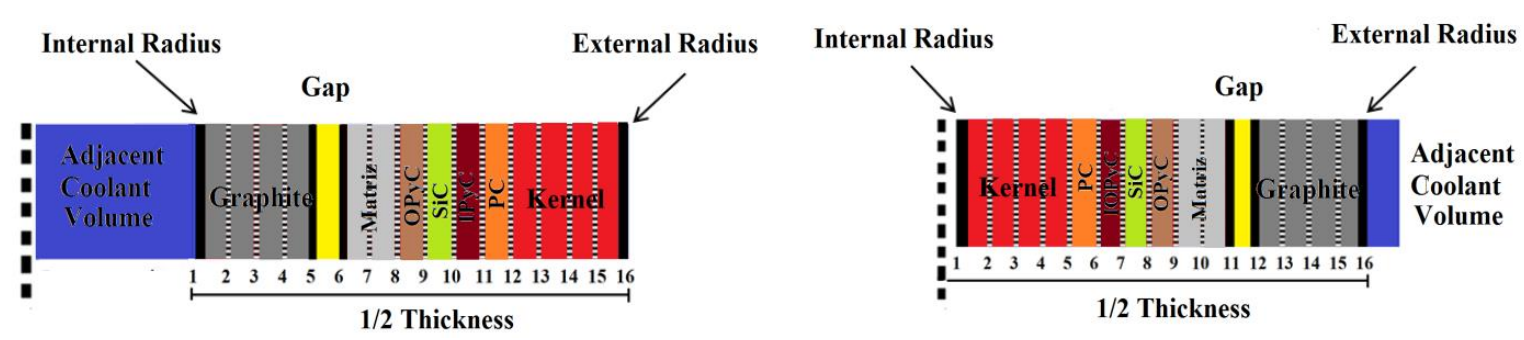

The thermodynamics properties of the LiF-BeF2 were selected to perform the calculations. The point kinetics option was used in the calculations, the data of volumetric heat capacity and heat transfer coefficient of the helium in the gap and the graphite were considered. The initial conditions used to simulate the core are shown in Table 2. 
Table 2: Initial conditions for the LS-VHTR [4].

\begin{tabular}{l|c}
\hline \multicolumn{1}{c|}{ Parameter } & Value \\
\hline Core total power & $2400 \mathrm{MW}$ \\
Core mass flow rate & $10,264 \mathrm{~kg} / \mathrm{s}$ \\
Core inlet temperature & $900{ }^{\circ} \mathrm{C}$ \\
Normal operation temperature limit & $1600{ }^{\circ} \mathrm{C}$ \\
Core outlet temperature & $1000{ }^{\circ} \mathrm{C}$ \\
Core pressure drop & $0.211 \mathrm{MPa}$ \\
\hline
\end{tabular}

The radial power distribution profile used in this work was that calculated by ORNL [4], and axial distribution factor or internal source multiplier value was specified for each axial segment of each HS. These values are multiplied by the total power to obtain the power generated by the heat structure [10]. The axial power profile chosen is based on a profile used to model the LS-VHTR as describe in [17].

\section{RESULTS}

The average temperatures in each material along any thermo-hydraulic channel axially, for annular and cylindrical geometry using the homogeneous and non-homogeneous model are shown in Figure 9. Each point represents an axial node from 1 up to 25. For the homogeneous model (with annular and cylindrical geometry) the behaviors of the fuel and gap temperatures have similar behavior in relation to the axial power distribution. For the graphite and liquid salt, the temperature increases uniformly. 
Figure 9: Axial temperature distribution along any heat structure.
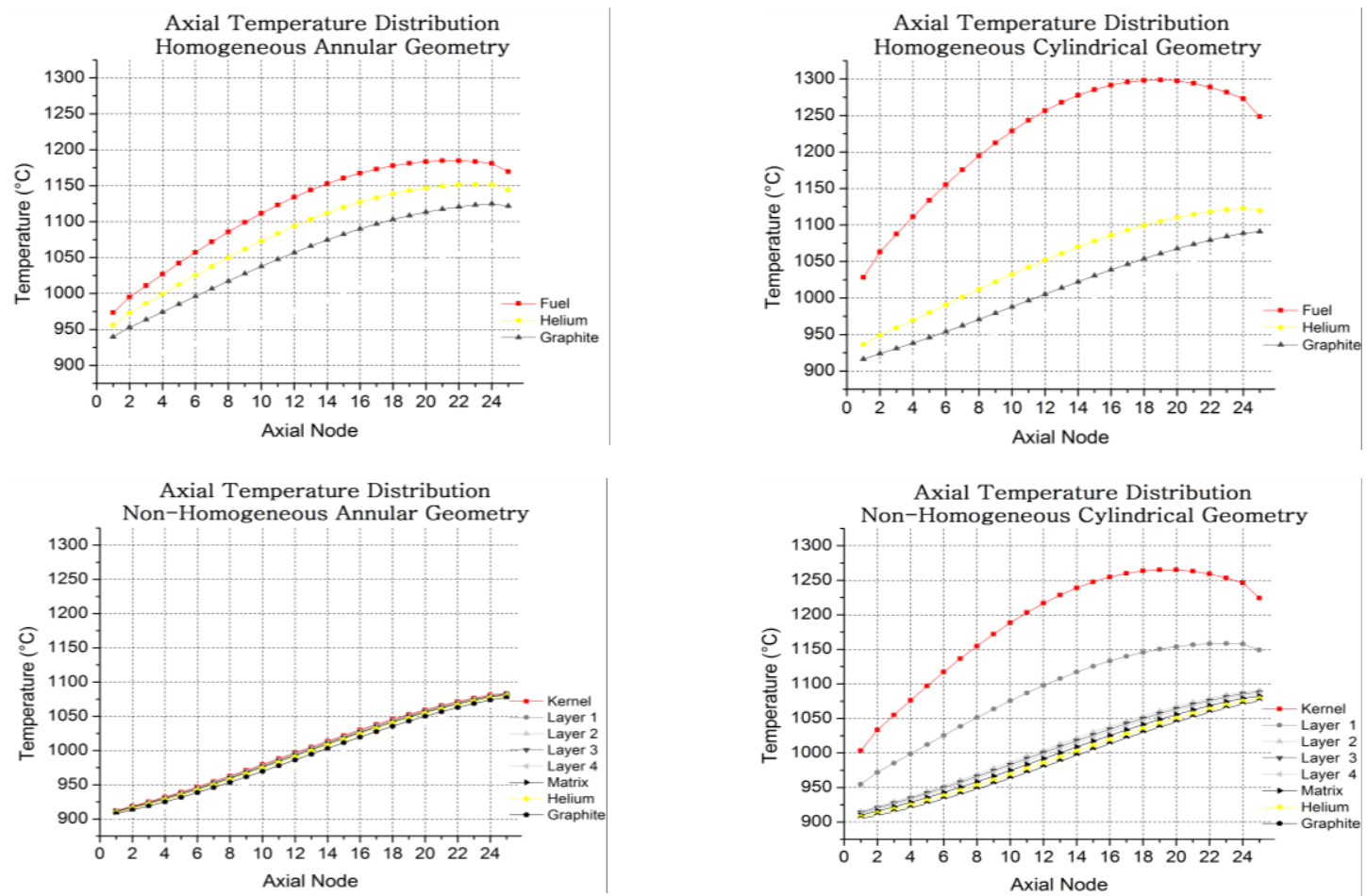

While the temperature distribution for the non-homogeneous model (with cylindrical geometry) has the same behavior of the homogeneous model, for the annular geometry the temperature increases uniformly in all material of the TRISO.

For the homogeneous and non-homogeneous model, the high average temperatures in the fuel were found in the cylindrical geometry $\left(1298.7^{\circ} \mathrm{C}\right.$ and $1271.4^{\circ} \mathrm{C}$ for both models respectively) and the lower temperatures in the annular geometry $\left(1187.5^{\circ} \mathrm{C}\right.$ and $1093.8^{\circ} \mathrm{C}$ for both models respectively).

In Figure 10 are shown the temperatures in the heat structures radially, for annular and cylindrical geometry using the homogeneous and non-homogeneous model. For the cylindrical geometry the temperature behavior in each axial node decreases from the radial mesh 1 to radial mesh 16, the high temperatures are located between the radial meshes 1 to 11 (represent the fuel compact) for the homogeneous model and 1 to 5 (Kernel) for the non-homogeneous model. The maxima temperatures are located in the radial mesh 1 and the axial nodes $18\left(1387.6^{\circ} \mathrm{C}\right)$ and $19\left(1282.0^{\circ} \mathrm{C}\right)$ for the homogeneous and non-homogeneous model, respectively. 
Figure 10: Radial temperature distribution along the heat structure.
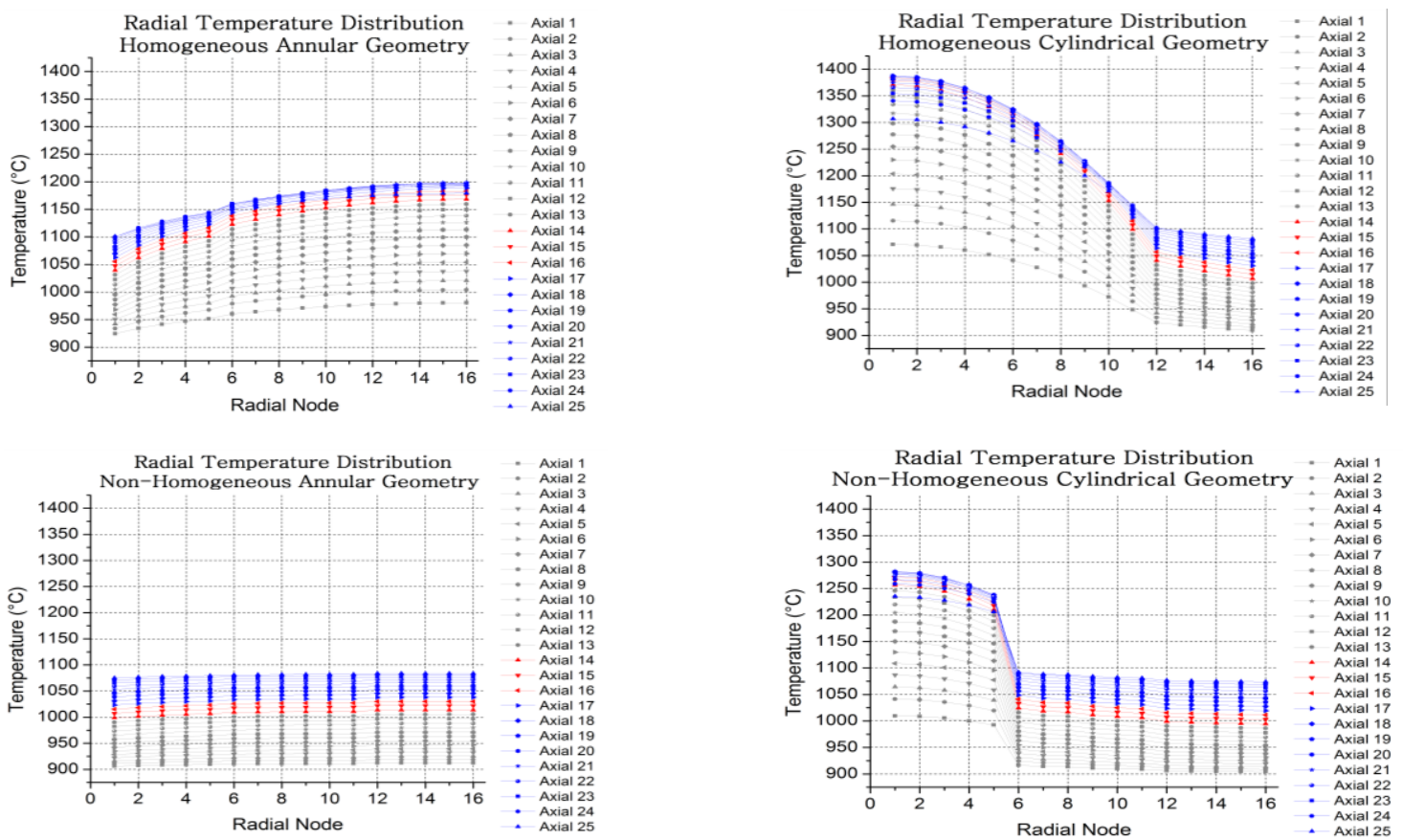

For the annular geometry the temperature behavior in each axial node increases from the radial mesh 1 to radial mesh 16, the fuel compact is represented from the radial mesh 6 to 16, and the Kernel is represented from the radial mesh 12 to 16 . The fuel maximum temperature is radially located in the radial mesh 16 and axially located in the axial nodes $21\left(1198.2^{\circ} \mathrm{C}\right)$ and $25(1083.7$ ${ }^{\circ} \mathrm{C}$ ) for the fuel compact and the kernel respectively.

The temperature distributions along the heat structure for annular and cylindrical geometries using the homogeneous and non-homogeneous model are shown in Figure 11. The maxima temperature distributions are displaced towards the upper region of the heat structure; these are located in the axial node 18 and 19 to the cylindrical geometry using the homogeneous and non-homogeneous model respectively; 21 and 25 to the annular geometry using both models respectively. 
Figure 11: Temperature distribution along any heat structure.
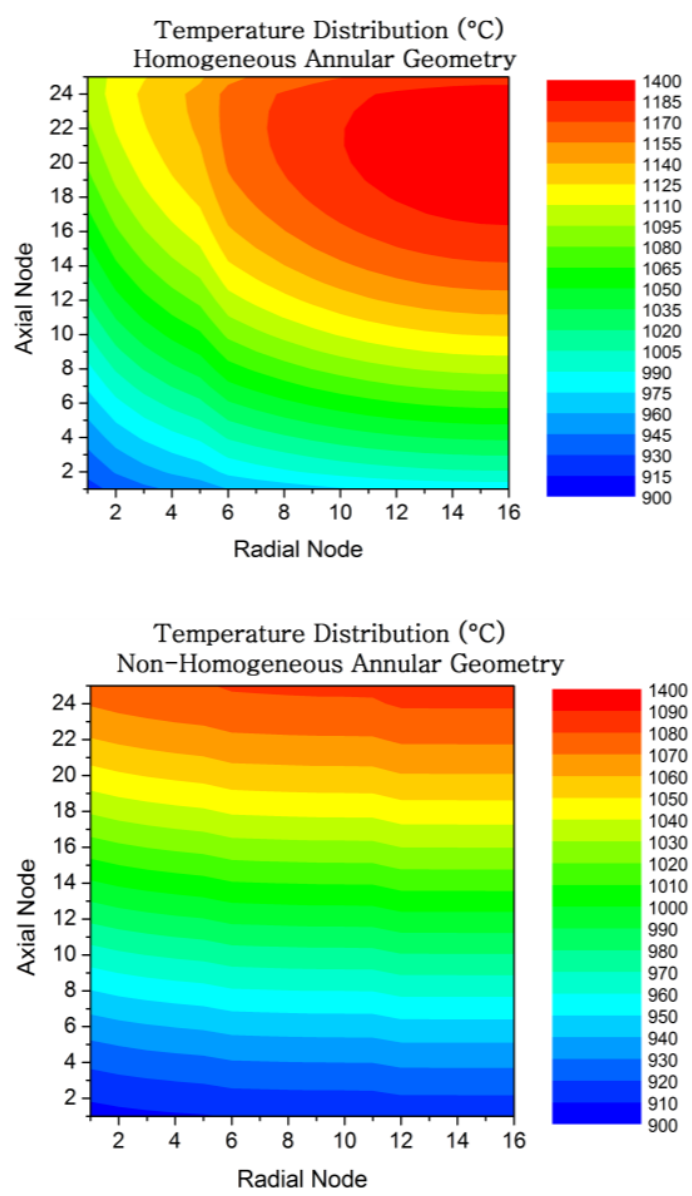
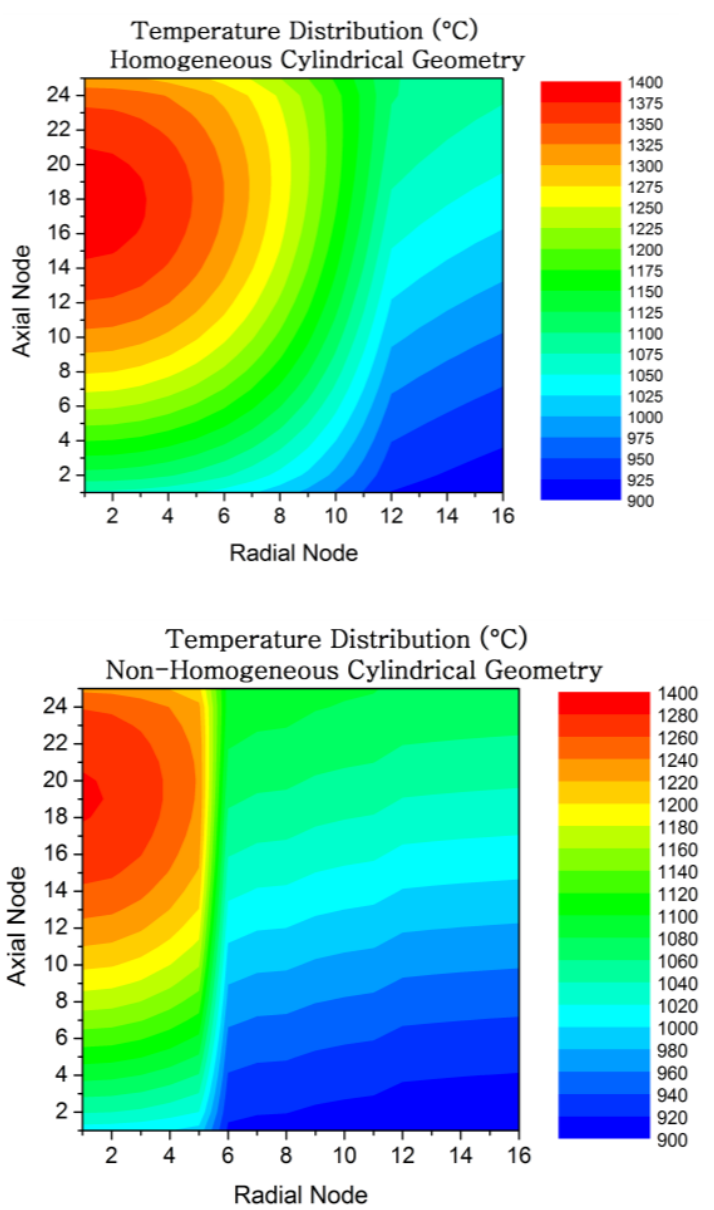

The high temperatures are located in a minor region for the cylindrical geometry; it is being smaller for the non-homogenous model. For the annular geometry, the high temperatures are located in a major region in comparison to the cylindrical geometry.

In the Table 3 is presented a comparison between the calculated results with the RELAP5-3D and the reference data for the steady state conditions. As it is possible to verify, in a general way, the simulated parameters are in good agreement with the reference data. 
Table 3: Main results of simulation

\begin{tabular}{|c|c|c|c|c|c|}
\hline \multirow{2}{*}{ Parameter } & \multirow{2}{*}{$\begin{array}{c}\text { Data } \\
\text { Reference } \\
{[4]}\end{array}$} & \multicolumn{2}{|c|}{ Homogeneous Model } & \multicolumn{2}{|c|}{$\begin{array}{c}\text { Non-Homogeneous } \\
\text { Model }\end{array}$} \\
\hline & & $\begin{array}{c}\text { Annular } \\
\text { Geometry }\end{array}$ & $\begin{array}{l}\text { Cylindrical } \\
\text { Geometry }\end{array}$ & $\begin{array}{c}\text { Annular } \\
\text { Geometry }\end{array}$ & $\begin{array}{c}\text { Cylindrical } \\
\text { Geometry }\end{array}$ \\
\hline Maximum Fuel Temperature $\left({ }^{\circ} \mathrm{C}\right)$ & $1600<$ & 1198 & 1387 & 1084 & 1282 \\
\hline $\begin{array}{l}\text { Average Temperature Kernel }\left({ }^{\circ} \mathrm{C}\right) \\
\text { Average Temperature } \operatorname{PC}\left({ }^{\circ} \mathrm{C}\right) \\
\text { Average Temperature } \operatorname{IPyC}\left({ }^{\circ} \mathrm{C}\right) \\
\text { Average Temperature } \operatorname{SiC}\left({ }^{\circ} \mathrm{C}\right) \\
\text { Average Temperature } \operatorname{OPyC}\left({ }^{\circ} \mathrm{C}\right) \\
\text { Average Temperature Matrix }\left({ }^{\circ} \mathrm{C}\right)\end{array}$ & - & 1119 & 1223 & $\begin{array}{l}1011 \\
1010 \\
1008 \\
1008 \\
1008 \\
1007\end{array}$ & $\begin{array}{c}1189 \\
1089 \\
1010 \\
1007 \\
1004 \\
999\end{array}$ \\
\hline Average Temperature of Helium $\left({ }^{\circ} \mathrm{C}\right)$ & - & 1085 & 1050 & 998 & 994 \\
\hline Average Temperature of Graphite $\left({ }^{\circ} \mathrm{C}\right)$ & - & 1054 & 1010 & 994 & 989 \\
\hline Average Temperature of Coolant $\left({ }^{\circ} \mathrm{C}\right)$ & - & 986 & 986 & 986 & 986 \\
\hline Outlet Coolant Temperature $\left({ }^{\circ} \mathrm{C}\right)$ & 1000 & 1003 & 1003 & 998 & 998 \\
\hline Drop Pressure (MPa) & 0.211 & 0.187 & 0.187 & 0.187 & 0.187 \\
\hline Mass Flow (kg/s) & 10.264 & 9991.1 & 9990.2 & 9991.1 & 9990.2 \\
\hline
\end{tabular}

One should note the non-homogenous model may not be the most accurate way to model the performance of the TRISO particles with the RELAP5 code, because this model not represent adequately the temperature distribution along of heat structure, nevertheless this model could be used to perform simulation of other parts of the cooling system without performing the modeling of the core reactor in great detail.

This result shows that the homogeneous model represents of manner adequate the TRISO fuel, however more investigations are necessary to account the effect of the TRISO particles in the fuel compact of a more realistic way. 


\section{CONCLUSION}

Thermal analysis of the LS-VHTR concept has been performed in this study using the RELAP5-3D code for a steady state simulation. The simulations of the thermal parameters of the reactor cooled by liquid Li2BeF4 (Flibe) salt presented similar behavior in relation to those of the reference data. The comparison between the simulated results and the reference data demonstrate that the developed model is capable to reproducing the thermal behavior of the reactor in steady state operation. More investigations are necessary mainly in relation to the heat transfer between the components of the heat structures. Future work consists in to incorporate more reactor details beyond the core in the model and also to simulate transient events.

\section{ACKNOWLEDGMENT}

The authors are grateful to the Comissão Nacional de Energia Nuclear (CNEN), the Coordenação de Aperfeiçoamento de Pessoal de Nível Superior (CAPES), the Fundação de Amparo à Pesquisa do Estado de Minas Gerais (FAPEMIG) and the Conselho Nacional de Desenvolvimento Científico e Tecnológico $(\mathrm{CNPq})$ for the support. Thanks also to Idaho National Laboratory (INL) for the license to use the RELAP5-3D computer software.

\section{REFERENCES}

[1] POWERS, J. J.; WIRTH, B. D. A Review of TRISO Fuel Performance Models, Journal of Nuclear Materials, v. 405, p. 74-82, 2010.

[2] INGERSOLL, D. T.; FORSBERG, C. W.; MACDONALD, P. E.; CLARNO, K. T.; FORSBERG, C. W.; GEHIN, J. C.; SLATER, C. Trade Studies for the Liquid-Salt-Cooled Very High-Temperature Reactor: Fiscal Year 2006 Progress Report, ORNL/TM-2006/140, Tennessee: Oak Ridge National Laboratory, 2006. 100p.

[3] ORTENSI J.; OUGOUAG A. M. Improved Prediction of the Doppler Effect in TRISO Fuel, In: INTERNATIONAL CONFERENCE ON ADVANCES IN MATHEMATICS, COMPUTATIONAL METHODS, AND REACTOR PHYSICS, 2009, New York. 
[4] INGERSOLL, D. T.; CLARNO, K. T.; FORSBERG, C. W.; GEHIN, J. C.; CHRISTENSEN, R. W.; DAVIS, C. B.; HAWKES, G. L.; STERBENTZ, J. W. Status of Physics and Safety Analyses for the Liquid Salt-Cooled Very High-Temperature Reactor (LS-VHTR), ORNL/TM2005/218, Tennessee, Oak Ridge National Laboratory, 2005. 264p

[5] JENSEN, C. TRISO Fuel Thermal Conductivity Measurement Instrument Development. 2010. Master's thesis. Utah State University. Logan, p. 838. (2010).

[6] FOLSOM, C. P. Effective Thermal Conductivity of Tri-Isotropic (TRISO) Fuel Compacts. 2012. Master's thesis. Utah State University. Logan, p. 94. (2012).

[7] G.A. - General Atomic, Gas Turbine-Modular Helium Reactor (GT-MHR) Conceptual Design Description Report, GA Project No. 7658, California: General Atomic, 1996.

[8] INGERSOLL, D. T.; FORSBERG, C. W.; OTT, L. J.; WILlIAMS D. F.; RENIER, J. P.; WILSON, D. F.; BALL S. J.; REID, L.; CORWIN, W. R.; DEL CUL, G. D. Status of Preconceptual Design of the Advanced High-Temperature Reactor (AHTR), Oak Ridge National Laboratory, ORNL/TM-2004/104, Tennessee: ORNL, 2004.

[9] QUALLS A. L.; WILSON T. L. Dynamic System Model of LS-VHTR to Estimate Design Parameter Impacts on Safety Margin and Reactor Economics, In: PROCEEDINGS OF ICAPP, 2006, Reno, Nevada, USA.

[10] The RELAP5-3D@ Code Development Team, RELAP5-3D@ Code Manuals, INEEL-EXT-9800834, Idaho National Laboratory (2009).

[11] DAVIS C. B.; HAWKES G. L. Thermal-Hydraulic Analyses of the LS-VHTR, In: PROCEEDINGS OF ICAPP, 2006, Reno, Nevada, USA.

[12] SCARI M. E.; COSTA A. L.; PEREIRA C.; VELOSO M. A. F.; SILVA C. A. M.; REIS P. A. L. Thermal hydraulic modeling of the LS-VHTR, In: PROCEEDINGS OF THE INTERNATIONAL NUCLEAR ATLANTIC CONFERENCE, 2013, Recife, Brazil.

[13] AVIGNI, P. Thermal Hydraulic Modeling of the Advanced High Temperature Reactor for the Evaluation of Steady State and Transient Conditions, Thesis. Politecnico dii Milano, Milano (2012).

[14] GROS, E. B. Liquid-Salt-Cooled Reactor Start-Up with Natural Circulation Under Loss-ofOffsite-Power (Loop) Conditions, Master's thesis, Georgia Institute of Technology, Georgia (2012).

[15] STAINSBY, R.; GRIEF, A.; WORSLEY, M.; HEERDEN, E. V.; DAWSON, F.; DENIIER, A.; BOWMAN, W. Investigation of Local Heat Transfer Phenomena in a Prismatic Modular Reactor Core. Toronto: AMEC NSS Limited, NR001/RP/001 R02, 2009.

[16] SHIN D. H.; CHO H. K.; Park G. C.; Tak N. I.; Yoon S. J. Evaluation of Effective Thermal Conductivity Models for the VHTR fuel block, In: PROCEEDINGS OF THE KNS 2015 SPRING MEETING, 2015, Republic of Korea,

[17] MACDONALD, P. E. NGNP Preliminary Point Design Results of the Initial Neutronics and Thermal-Hydraulic Assessments, Idaho: INEEL/EXT-03-00870, 2005. 